\section{Grazing Effects on Runoff and Vegetation on Western South Dakota Rangeland ${ }^{1}$}

\author{
GLAYTON L. HANSON, ARMINE R. KUHLMAN, CARL J. \\ ERICKSON, AND JAMES K. LEWIS
}

\author{
Agricultural Engineer, USDA, Rapid City, South Dakota, Botanist \\ and Soil Scientist, USDA, Newell, South Dakota and Associate \\ Professor of Animal Science, South Dakota State University.
}

\section{Highlight}

Four 2-acre watersheds were established in 1962 on each of three pastures that had been grazed at different intensities (heavy, moderate and light) since 1942. These watersheds were located at the Cottonwood Range Field Station, Cottonwood, South Dakota. The mean seasonal runoff from May 14 through October 31 for 1963 through 1967 was $0.79,0.56$ and 0.42 inch for the heavily, moderately and lightly used watersheds, respectively. The mean weight of live and dead standing crop of vegetation plus mulch in late July was 1,752, 2,092 and 3,700 pounds per acre for the heavily, moderately and lightly used watersheds, respectively.

With the need for increased production from rangelands, the knowledge of how watersheds function under various grazing intensities is of interest. Runoff was not affected by different grazing intensities in the Chaparral Watersheds of central Arizona (Rich and Reynolds, 1963). A study in the Berkeley Hills, California showed that the annual runoff from heavily grazed, lightly grazed, and ungrazed plots was different (Liacos, 1962). The heavily grazed plots yielded 9.25 inches of runoff and the lightly grazed yielded 4.02 inches. Infiltrometer studies conducted in 1964 on native rangeland at Cottonwood, South Dakota (Rauzi and Hanson, 1966), indicated that during the first 30 minutes the water intake rate on the heavily used pasture was 1.40 inches per hour and the rate on the light use pastures was 3.19 inches per hour.

\section{Study Area and Procedures}

The study reported herein was conducted in connection with long term grazing studies at the Cottonwood Range Field Station, Cotton-

\footnotetext{
${ }^{1}$ Contribution from the Soil and Water Conservation Research Division, Agricultural Research Service, USDA, and the South Dakota Agricultural Experi ment Station. Received July 8, 1969; accepted for publication July 6,1970 .
}

wood, South Dakota (Fig. 1). The mean annual precipitation at the Field Station was 15.22 inches for a 58-year period from 1910 through 1967, of which 11.94 inches fall during the growing season (April-September). The average annual temperature is about $47 \mathrm{~F}$.

The Chestnut soils of the watersheds have been classified in the Opal-Samsil associations (Westin, Puhr, and Buntley, 1967). In general, the soils are dark brown, moderately deep, slowly permeable, heavy clays derived from the Pierre formation.

The vegetation on the normal uplands is composed primarily of short grasses and midgrasses. The short grasses and sedges include buffalograss (Buchloe dactyloides) (Hitchcock, 1950), blue grama (Bouteloua gracilis), threadleaf sedge

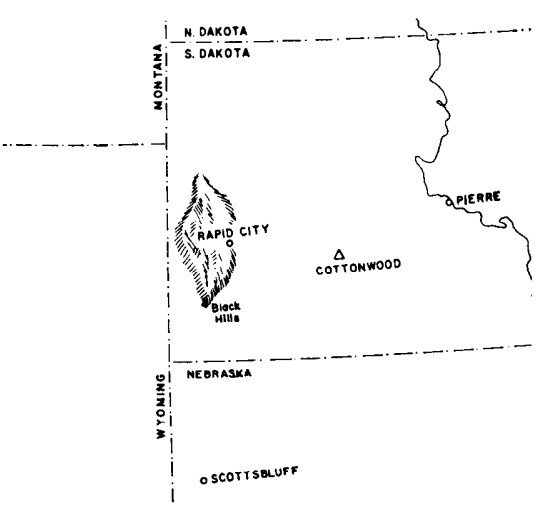

FIc. 1. Location Map.
(Carex filifolia), needleleaf sedge (Carex eleocharis), and Sandberg bluegrass (Poa secunda). The midgrasses include western wheatgrass (Agropyron smithii), needleandthread (Stipa comata), green needlegrass (Stipa viridula), sideoats grama (Bouteloua curtipendula), and little bluestem (Andropogon scoparius).

The range pastures had been grazed heavily, moderately, and lightly during the summers from 1942 through 1967. Fixed stocking rates wcre used through 1951 . Since 1952 "put-and-take animals" have been used to assure forage utilization to over 55 percent for the heavy use, 35 to 55 percent for the moderate use, and less than 35 percent for the lightly used pasture (Lewis et al., 1956). Hereafter heavy, moderate, and light grazing use will be referred to as heavy, moderate, and light.

Previous to the inception of the grazing intensity study, this mixed prairie area was dominated largely by midgrasses with an understory of short grasses and sedges (Lewis et al., 1956). In the last 26 years under three intensities of controlled grazing, the midgrasses have decreased on the moderate and heavy pastures, leaving the short grasses and sedges. Japanese brome (Bromus japonicus), invaded the area in the early 1950's becoming most prevalent in the light pastures.

Watershed study areas in each of three differentially grazed pastures were established in 1962. Confining dikes were constructed on four 2acre contiguous watersheds (Fig. 2) on each of the three pastures. The slope averages $7.9,7.6$ and $7.8 \%$, respectively, for the heavy, moderate, and light watersheds. Each set of watersheds has a northeast aspect. The light and heavy watersheds lie about $1 / 4$ mile on either side of the moderate watersheds. Two-foot $\mathrm{H}$-flumes and FW-1 waterstage recorders measure runoff. Four 8-inch recording rain gages measure the precipitation on each set of watersheds. Only the rainfall runoff from May 14 through October 31 was used in this report because there 


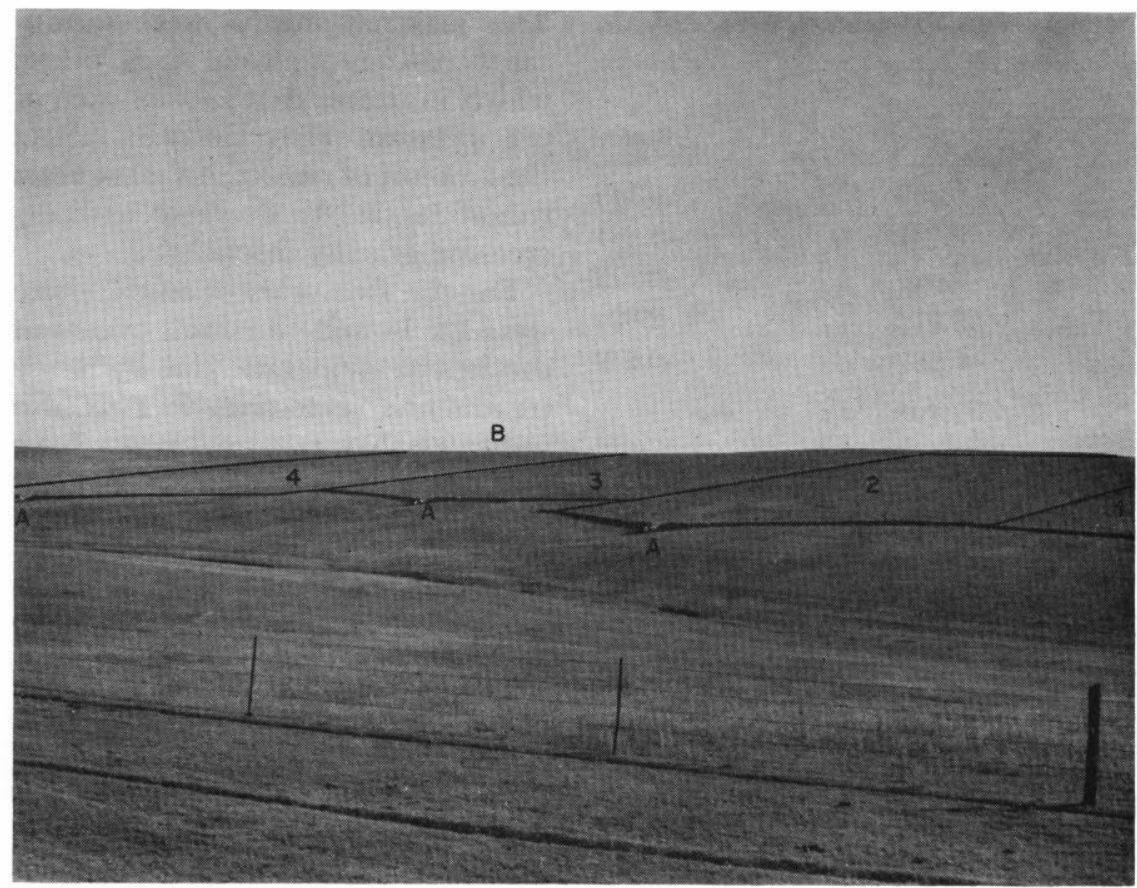

FIG. 2. Moderately grazed watersheds. $(1-4)=$ watersheds; $(A)=2$-foot H.-flume; (B) $=$ recording rain gage.

was no snowmelt runoff during this period.

Vegetation samples were harvested in late July from transects within each watershed from 1963 through 1967. Samples were taken at ground level to include remaining litter.

An analysis of variance, based on a split-plot design, was used to determine the effects of the different grazing intensities on runoff and vegetation. This analysis was based on the assumption that physiological conditions of all the watersheds were the same prior to 1942 . The runoff data followed a log-normal distribution so a $\log$ transformation was used. A 0.02 inch was added to each runoff value so that there were no zeros in the data used in the analysis. The means were separated using Tukey's test (Snedecor, 1956).

\section{Results}

Data are presented for the years 1963 through 1967. The seasonal precipitation from May 14 through October 31 is listed in Table 1 . The total mean seasonal precipitation varied from 8.30 inches in 1964 to 12.26 inches in 1963, with a 5-year mean of 10.37 inches. The 5 -year seasonal mean is about twothirds of the mean annual precipitation in the vicinity of the watersheds. Precipitation variations appear to be about the same within watersheds as between watersheds. There was no indication of a rainfall pattern within this study area.

Yields of live and standing dead vegetation plus litter, as affected by years and grazing, are displayed in Table 2. Differences between the five-year means of each grazing treatment were significant at the

Table 1. Seasonal (May 14-Oct. 31) precipitation (inches) and runoff (inches) from the differentially grazed watersheds.

\begin{tabular}{|c|c|c|c|c|c|c|}
\hline \multirow[b]{3}{*}{ Year } & \multicolumn{6}{|c|}{ Watersheds by grazing treatment } \\
\hline & \multicolumn{2}{|l|}{ Heavy } & \multicolumn{2}{|c|}{ Moderate } & \multicolumn{2}{|l|}{ Light } \\
\hline & Precipitation & Runoff & Precipitation & Runoff & Precipitation & Runoff \\
\hline 1963 & $12.14^{1}$ & $1.79^{2}$ & 12.02 & 1.57 & 12.61 & 1.39 \\
\hline 1964 & 8.59 & 0.66 & 8.58 & 0.28 & 7.74 & 0.05 \\
\hline 1965 & 10.81 & 0.13 & 11.05 & 0.14 & 10.91 & 0.12 \\
\hline 1966 & 9.40 & 0.16 & 9.18 & 0.02 & 9.45 & 0.00 \\
\hline 1967 & 11.00 & 1.21 & 11.16 & 0.79 & 10.90 & 0.54 \\
\hline Mean & 10.39 & 0.79 & 10.40 & 0.56 & 10.32 & 0.42 \\
\hline
\end{tabular}

Table 2. Total weight (lbs./acre, oven-dry) of live vegetation, standing dead and mulch on differentially grazed watersheds in late July, 1963-1967, by grazing intensity and year.

\begin{tabular}{lc}
\hline \hline Item & Weight $^{\mathrm{a}}$ \\
\hline Grazing intensity & \\
Heavy & $1752^{\mathrm{a}}$ \\
Moderate & $2092^{\mathrm{b}}$ \\
Light & $3700^{\mathrm{c}}$ \\
Year & \\
1963 & $2016^{\mathrm{a}}$ \\
1967 & $2256^{\mathrm{a}, \mathrm{b}}$ \\
1966 & $2436^{\mathrm{b}}$ \\
1965 & $2864^{\mathrm{c}}$ \\
1964 & $3004^{\mathrm{c}}$ \\
\hline
\end{tabular}

${ }^{1}$ Means with the same superscript are not statistically different from each other at the 0.05 level of significance. Least significant difference between the means at the 5 percent level: Grazing-324; year332.

five percent level, while differences between the light watershed and the other treatments were significant at the one percent level. Following a period of dry years, the above average precipitation in 1962 increased the weights of vegetation and mulch with the greatest effect being in 1964. The weights of these materials declined each subsequent year. Precipitation distribution was erratic and the wet season was not always in May and June.

Mean oven-dry weights of live vegetation were 520, 561 and 937 pounds per acre from the heavy, moderate and light watersheds, 
Table 3. Logarithmic means of runoff (May 14-Oct. 31) from the watersheds.

\begin{tabular}{lcccr}
\hline \hline & \multicolumn{3}{c}{ Grazing treatment } & \\
\cline { 2 - 4 } Year & Heavy & Moderate & Light & Mean \\
\hline 1963 & $0.584^{1}$ & 0.452 & 0.300 & 0.445 \\
1964 & -0.431 & -1.281 & -2.731 & -1.481 \\
1965 & -2.179 & -1.814 & -2.044 & -2.012 \\
1966 & -1.753 & -3.408 & -3.912 & -3.024 \\
1967 & +0.187 & -0.256 & -0.587 & -0.219 \\
Mean & -0.718 & -1.261 & -1.795 & \\
\hline
\end{tabular}

${ }^{1}$ Mean of four watersheds. Significant difference among the means at the 5 percent level: Year-0.351; treatment-0.353.

respectively. The corresponding standing dead and mulch weights were $1,232,1,531$ and 2,763 pounds per acre, respectively.

The effects of grazing intensity are also reflected in the botanical composition. Short grasses and sedges predominated in the heavy watersheds while western wheatgrass was important in the mixture of grasscs on the light watersheds. A limited amount of midgrasses occurred among the predominantly short grasses on the moderate areas.

The average seasonal runoff was $0.79,0.56$ and 0.42 inch from the heavy, moderate and light watersheds, respectively (Table 1). Runoff was greatest in 1963 when heavy watersheds produced 1.79 inches, and least in 1966 when there was no runoff from the light watersheds. The heavy watersheds had the most runoff 4 out of the 5 years. In 1965 , the moderate watersheds yielded the most runoff but the difference among the three sets of watersheds was only 0.02 inch. The light watersheds produced the least runoff every year of the study.

During this study runoff occurred in May and June every year except 1966. There was some runoff in July of 1963 and 1964 and in August and September of 1966. Most of the runoff during 1963 was from two 3-inch rains. The first event was a very high intensity rain and the heavy treatment yielded the most runoff. The second event was of lower intensity but it followed a period of high rainfall and the light watersheds produced the most runoff.
Runoff during 1964 was produced by seven events on the heavy but only three of these produced runoff on the moderate and light. The three events that produced runoff from all the treatments had maximum 10-minute intensities greater than 2.7 inches per hour but had less than 1 inch of rainfall. None of the seven events exceeded 1 inch of prccipitation.

During 1965, two storms caused most of the runoff. The first was a 2-inch rain and the second was only a 0.64 -inch rain. However, the second storm followed a period of abundant rain and the runoff was greater than from the first event.

Runoff for 1966 was from one event in August and one event in September. This was the only year runoff occurred during August and September. Although more than 2 inches of rain were received in each of these two storms, there was no runoff from the light watersheds, probably because of the dry conditions preceding these events. There were four runoff events during 1967 on the heavy and only one on the light treatment. The event that produced runoff from the light use treatment had about 2.3 inches of precipitation and followed a period of heavy precipitation.

Logarithmic mean values of runoff for treatment means and seasonal means are listed in Table 3. Mean runoff values were significantly different at the 5 percent level between all treatment means, indicating that the three grazing regimes have affected the runoff.
The seasonal means were significantly different from each other, which indicates that factors such as precipitation characteristics affect the amount of runoff. In most years runoff tended to decrease with decreasing grazing intensity.

For the five years of study, there were 22, 18 and 13 runoff events in the heavy, moderate and light use treatments, respectively. This also indicates that the treatments have affected the runoff regime. The data indicate that the heavy watersheds have runoff from short, intense storms as well as from long. duration storms, whereas the light watersheds have most of their runoff from long-duration storms that follow periods of antecedent precipitation. The data also suggest that the runoff from a long-duration storm may be as much from the light watersheds as from the moderate and heavy watersheds, especially if the storm follows a wet period.

\section{Literature Cited}

Hiтchсоск, A. S. 1950. Manual of the grasses of the United States, 2nd Ed. (revised by Agnes Chase). U.S. Dcp. Agr. Misc. Pub. 200, 1051 p.

Lewis, James K., George M. Van Dyne, Leslite R. Albee, and Frank W. WHETZAL. 1956. Intensity of grazing-its effect on livestock and forage production. South Dakota Agr. Exp. Sta. Bull. 459, Brookings, S.D., 44 p.

Liacos, Leonidas G. I962. Water yield as influenced by degree of grazing in the California winter grasslands. J. Range Manage. 15:34-42.

Rauzi, Frank, and Clayton L. HanSON. 1966. Water intake and runoff as affected by intensity of grazing. J. Range Manage. 19:351-356.

Rici, Lowell R., and Hudson G. ReYNoLDS. 1963. Grazing in relation to runoff and erosion on some Chaparral watersheds in Central Arizona. J. Range Manage. 16:322-326.

SNEDECOR, GEORGE W. 1956. Statistical methods applied to experiments in agriculture and biology. The Iowa State College Press, Ames, Iowa. $534 \mathrm{p}$.

Westin, Fred C., Leo F. Puhr, and George J. Buntley. 1967. Soils of South Dakota. Soil Survey Series No. 3. South Dakota Agr. Exp. Sta., Brookings, S.D. 32 p. 